\section{Cureus}

Received 10/20/2015

Review began 10/23/2015

Review ended 10/24/2015

Published 11/06/2015

\section{(c) Copyright 2015}

Bhatti et al. This is an open access article distributed under the terms of the Creative Commons Attribution License CC-BY 3.0., which permits unrestricted use, distribution, and reproduction in any medium, provided the original author and source are credited.

\title{
Chronic Renal Transplant Rejection and Possible Anti-Proliferative Drug Targets
}

\author{
Adnan Bashir Bhatti ${ }^{1}$, Muhammad Usman ${ }^{2}$ \\ 1. Medical Director of Clinical Research, Spine Surgery, Tristate Brain and Spine Institute, United States, \\ Atlanta, USA 2. Department of Medicine, Jinnah Hospital Lahore (JHL)/Allama Iqbal Medical College \\ (AIMC), Lahore, Pakistan
}

$\square$ Corresponding author: Adnan Bashir Bhatti, dr.adnanbashir@gmail.com Disclosures can be found in Additional Information at the end of the article

\section{Abstract}

The global prevalence of renal transplants is increasing with time, and renal transplantation is the only definite treatment for end-stage renal disease. We have limited the acute and late acute rejection of kidney allografts, but the long-term survival of renal tissues still remains a difficult and unanswered question as most of the renal transplants undergo failure within a decade of their transplantation.

Among various histopathological changes that signify chronic allograft nephropathy (CAN), tubular atrophy, fibrous thickening of the arteries, fibrosis of the kidney interstitium, and glomerulosclerosis are the most important. Moreover, these structural changes are followed by a decline in the kidney function as well. The underlying mechanism that triggers the long-term rejection of renal transplants involves both humoral and cell-mediated immunity. $\mathrm{T}$ cells, with their related cytokines, cause tissue damage. In addition, CD 20+ B cells and their antibodies play an important role in the long-term graft rejection. Other risk factors that predispose a recipient to long-term graft rejection include HLA-mismatching, acute episodes of graft rejection, mismatch in donor-recipient age, and smoking.

The purpose of this review article is the analyze current literature and find different antiproliferative agents that can suppress the immune system and can thus contribute to the longterm survival of renal transplants. The findings of this review paper can be helpful in understanding the long-term survival of renal transplants and various ways to improve it.

Categories: Allergy/Immunology, Nephrology, Transplantation

Keywords: renal transplant, rejection, drug targets

\section{Introduction And Background}

Kidney transplantation is the only effective treatment option for managing end-stage renal disease. According to statistics, 75,000 kidney transplants were done globally in the year 2010, and these statistics are expected to rise to 350,000 (almost three to four times the baseline value) in the coming years [1]. Figure 1 depicts the kidney transplantation activities of 2012; Figure 2 depicts the region-wise rate of kidney transplantation. 


\section{Cureus}

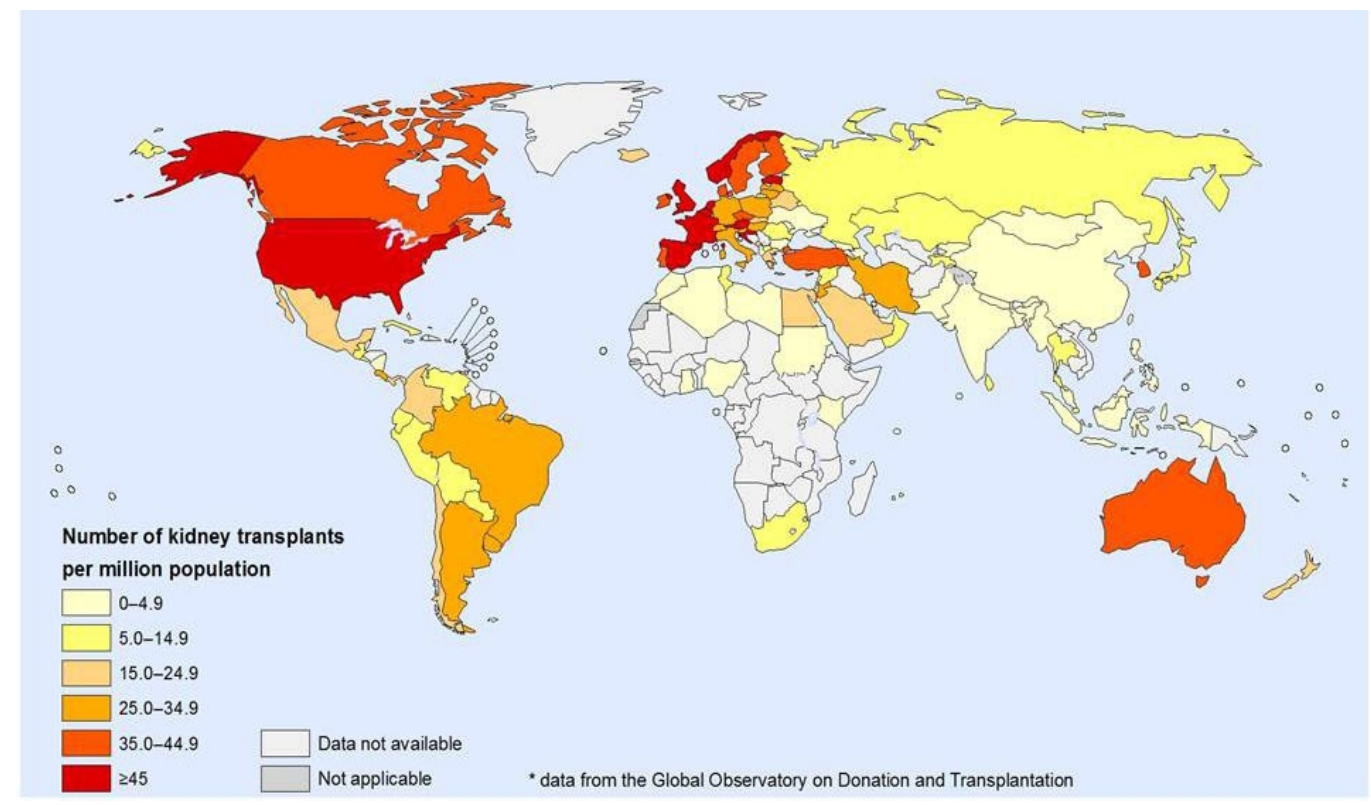

\section{FIGURE 1: Kidney transplantation activities, 2012}

Data from Global Observatory on Donation and Transplantation (GODT) data, produced by the WHOONT collaboration

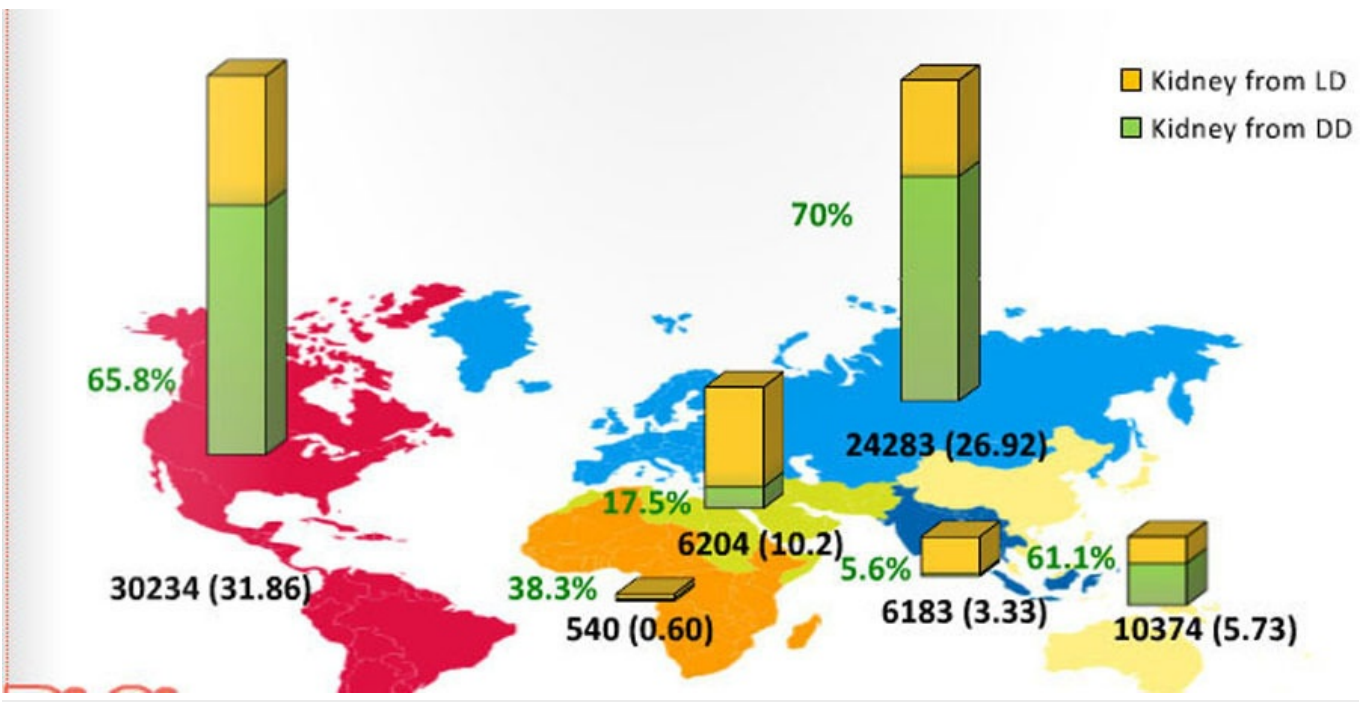

\section{FIGURE 2: Kidney transplantation per region}

Data from Global Observatory on Donation and Transplantation (GODT) data, produced by the WHOONT collaboration

Transplant rejection is one of the biggest limitations in renal transplant procedures, where the kidney can undergo an acute, late acute, or chronic transplant rejection [2-3]. With the advancement in transplantation protocols, acute and long-term survival of renal transplants has improved [4], but long-term survival is still unsatisfactory. Acute transplant rejection has experienced a significant fall due to the use of immunosuppressant therapy, but most of the renal transplants develop chronic graft rejection within a decade [1, 5-6]. In addition to that, the long- 
term mortality rates among patients with renal transplants are observed to be significantly higher when compared to that seen in the general population [7]. Unfortunately, there is little we know when it comes to improving long-term survival of renal transplants. Therefore, time is of the utmost importance in understanding the underlying mechanism of long-term renal transplant rejection and explore different drug targets that can improve survival of both the graft and the patient.

\section{Review}

A successful kidney transplantation is a much better option to improve the quality and longevity of chronic and/or end-stage renal disease patients. This is especially true when dialysis is the only other option. Dialysis procedure is very time-consuming, expensive, and requires frequent hospital visits. Kidney transplantation is thus a viable alternative. However, transplantation also has a fair share of disadvantages, the major constraint being renal transplant rejection.

\section{Histological and clinical features of chronic renal transplant rejection}

Chronic renal transplant rejection is the result of a gradual decrease in the kidney function that starts to become evident three months after the transplantation surgery. Hypertension and proteinuria are the most important features of declining renal function [8-9]. Moreover, analysis of the serum creatinine concentration has shown that at least $80 \%$ of patients experience progressive loss of kidney function and start to exhibit signs of chronic allograft nephropathy (CAN) [10]. At least 50\% of the patients with renal transplant develop features of CAN within 10 years of their transplant [11]. The major pathological features of CAN includes tubular atrophy, fibrous thickening of the arteries, fibrosis of the kidney interstitium, and glomerulosclerosis [12$13]$.

Transplant vasculopathy is the single most important feature of chronic renal transplant rejection [14]. Vasculopathy not only affects the large arteries but can also involve small peritubular capillaries [15]. The most important features of transplant vasculopathy include thickening of the fibrointima of the blood vessels, infiltration of the vessel walls with inflammatory cells, and breaks in the elastic layer of blood vessels. The subendothelial accumulation of smooth muscles in transplant vasculopathy was previously thought to be the result of migration of donor myofibroblasts from the media of the adjacent blood vessels. However, recent evidence has suggested that these smooth cells are from the recipient and are derived from the precursor cells present in the circulation [14-17]. The glomerular lesions seen in the biopsies obtained from the cases of CAN show wrinkling of the glomerular tuft of capillaries, focal glomerulosclerosis, hypertrophy of the glomeruli, and expansion of the mesangial matrix [18-20].

Transplant glomerulopathy can be distinguished from other forms of glomerulopathy like membranoproliferative glomerulonephritis (MPGN), based on the results of electron and immune-fluorescence testing. MPGN is characterized by electron-dense deposits, whereas the deposits seen in transplant glomerulopathy are electron lucent. Moreover, the immune deposits seen in MPGN patients are predominantly C3, whereas the main type of deposits in patients with transplant glomerulopathy is of the IgM type [21].

\section{Risk factors for chronic renal transplant rejection}

The risk factors for chronic renal transplant rejection are described in Table 1. 


\section{Cureus}

\begin{tabular}{|c|c|c|c|}
\hline $\begin{array}{l}\text { Factors for Increased Graft } \\
\text { Rejection }\end{array}$ & $\begin{array}{l}\text { Survival of the } \\
\text { Graft }\end{array}$ & Factors for Better Graft Survival & $\begin{array}{l}\text { Survival of the } \\
\text { Graft }\end{array}$ \\
\hline Acute transplant rejection episodes & 6.6 years & No acute transplant rejection episodes & 12.5 years \\
\hline Non- HLA matched grafts & 8.6 years & HLA matched graft & 12.4 years \\
\hline Recipient age $<14$ years & $\begin{array}{l}\text { Less chances of } \\
<5 \text { years survival }\end{array}$ & Recipient age $>14$ years but $<70$ years & $\begin{array}{l}\text { More chances of } \\
>5 \text { years survival }\end{array}$ \\
\hline $\begin{array}{l}\text { Donor-Recipient Mismatch (Young } \\
\text { recipient-Old donor) }\end{array}$ & 8.7 years & $\begin{array}{l}\text { Donor-Recipient Match (Young } \\
\text { recipient-Young donor) }\end{array}$ & 11.64 years \\
\hline Black Race & 7.2 years & White Race & 13.3 years \\
\hline $\begin{array}{l}\text { Antibodies to both class } 1 \text { and class } 2 \\
\text { HLA antigens ( } 2 \text { years survival) }\end{array}$ & $71 \%$ & $\begin{array}{l}\text { Antibodies to either HLA class } 1 \text { or } \\
\text { class } 2 \text { antigens ( } 2 \text { years survival) }\end{array}$ & $\begin{array}{l}77 \% \text { and } 79 \% \\
\text { respectively }\end{array}$ \\
\hline
\end{tabular}

TABLE 1: Comparison of the major risk factors governing survival of renal transplants

\section{Acute transplant rejection episodes}

The long-term survival of renal transplants is relatively shorter in those patients who experience episodes of acute transplant rejection as compared to patients who do not experience such episodes. The mean survival in patients with acute rejection patients vs. patients with no such episodes is 6.6 years and 12.5 years, respectively [22].

\section{Human leukocyte antigen (HLA) mismatching}

Major histocompatibility complex (MHC) molecules on the transplanted kidney are the primary targets of the kidney recipient's immune system. Therefore, HLA matching can save a lot of transplants from rejection. The mean survival for the HLA-mismatched vs. HLA-matched transplants is 8.6 years and 12.4 years, respectively [23].

\section{Sensitization to HLA antigen}

Pre-sensitization to Class 1 and Class 2 HLA is another important risk factor for chronic transplant rejection. Patients who are positive for the antibodies against Class 1 and Class 2 HLA usually have a poor long-term survival rate [24-26]. The two-year survival rate in individuals positive for anti-HLA Class 1 antibodies, anti-HLA Class 2 antibodies, and both Class 1 and Class 2 HLA antibodies is 77\%, (vs. 84\% anti-HLA Class 1 antibody-negative individuals), 79\% (vs. 84\% anti-HLA Class 2 antibody-negative individuals) and 71\% (vs. no deleterious effects in individuals with a well-matched kidney), respectively [27].

\section{Recipient age}

Younger recipients are more likely to suffer chronic renal transplant failure as compared to older individuals. Younger patients have a more responsive immune system and show poor compliance to immunosuppressive therapy [28-29]. A recent study has demonstrated that the five-year survival of grafts in younger children (< 14 years) is much lower when compared to that of individuals of other age groups [30]. 


\section{Match of donor-recipient age}

Better matching of donor-recipient age is another important factor that can improve the outcomes of renal transplant. The mean survival of renal transplants in younger recipients receiving transplants from younger donors is 11.64 years as compared to the mean survival of 8.7 years in younger patients who receive grafts from older donors [31].

\section{Race}

The chances of graft rejection are greater among blacks as compared to whites [32-33]. This difference is perhaps due to the difference in immune responsiveness among two groups [34]. The mean survival of grafts in blacks as compared to whites is 7.2 years and 13.3 years, respectively [4].

\section{Other risk factors}

Other factors that may increase the risk of chronic renal transplant failure include loss of renal function [35], hypertension [36], proteinuria one-year post-transplantation [37], hyperlipidemia [38], and smoking [39].

\section{Pathophysiology of chronic renal transplant rejection}

The fundamental component of chronic graft rejection is the detection of antigens on the donor's tissues as "foreign entities" by the recipient's immune system. However, the degree of immune reaction, and thereby degree and speed of graft rejection, depends on the histocompatibility between donor and recipient, as HLA matched grafts survive longer as compared to HLAmismatched grafts [40-41]. The activation of the immune system involves two distinct pathways: the direct and the indirect pathway (Figure 3). The direct way involves the activation of CD4+ T cells by the donor's antigen presenting cells (APC). The indirect pathway involves the processing of the donor's graft antigens by recipient's APC that then activates the immune cells [42]. The indirect activation can stimulate the activity of activated B cells, which then leads to the production of antibodies against the graft tissues. These antibodies seem to play a very important role in chronic graft rejection [43-44]. 


\section{Cureus}

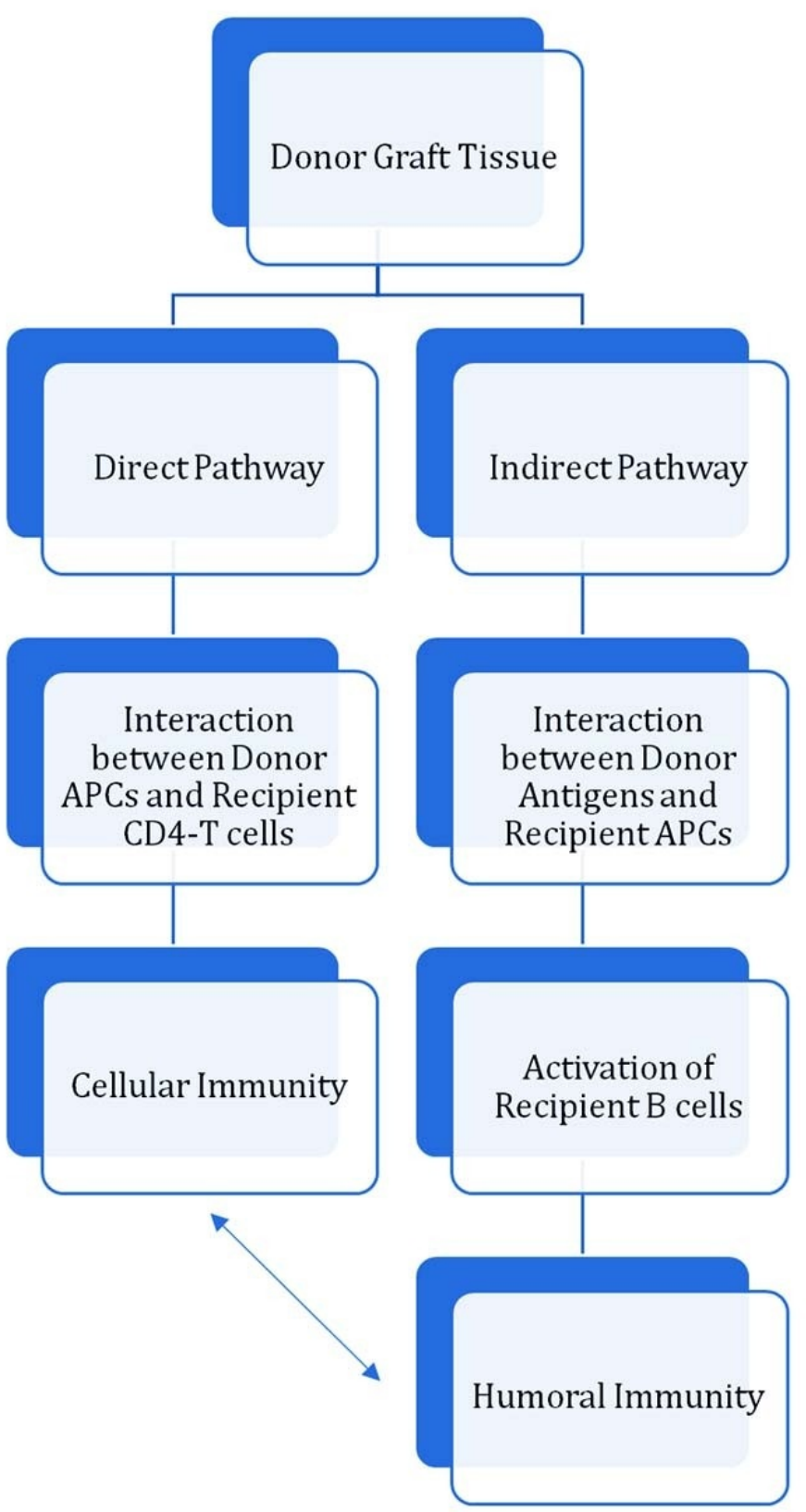

FIGURE 3: A scheme showing direct and indirect pathways for allograft rejection

APCs: Antigen Presenting Cells

Cellular immunity has only a minor role in the chronic allograft rejection. Studies have shown that an indirect pathway is the main predictor for chronic allograft rejection [45-46]. The only role T cells play in chronic transplant rejection is via cytokines secreted by Type 2 helper lymphocytes (Th2). Several studies have shown that the cytokines secreted by Th2, like IL-4, IL5, IL-6, IL-10, and IL-13, are responsible for reactions, such as tissue fibrosis and chronic rejection [47-48]. This fact has been further validated in studies where the injection of Th2 cells in immune-deficient recipients resulted in chronic graft rejection [49]. Blocking the effect of Th2released cytokines can seemingly slow down the process of allograft rejection, which has been demonstrated through studies where the fibrosis in skin grafts was prevented via injection of 
anti-IL-4 antibodies [5]. The cytokines produced by Th2 cells causes allograft rejection through different ways. For instance, IL-4 stimulates the activity of fibroblast cells that increase the production of extracellular matrix and speed up the process of fibrosis. Similarly, a high titer of IL-10 inhibits the production of metalloproteinase by macrophages, the basic function of which is to digest excessive extracellular matrix [51-52]. Moreover, the cytokines produced by Th2 cells also promote the production of antibodies [53].

As previously mentioned, the basic role in allograft rejection - whether acute of chronic - is played by B cell and anti-HLA antibodies. The presence of plasma cells and CD20+ B cells in the allografts have been found to be associated with irreversible allograft injury [54-55]. The diagnosis of chronic (or acute) antibody-mediated allograft rejection is based on the presence of three different features: (i) presence of anti-donor antibodies, as indicated by serology, (ii) C4d, a complement split product, positive staining in the peritubular capillaries, and (iii) morphological features of chronic (or acute) renal tissue injury [56-57]. As already mentioned, cellular immunity accentuates humoral immunity, and humoral immunity accentuates cellular immunity. Humoral immunity damages the graft by the production of anti-graft antibodies via activation of $\mathrm{T}$ cells through an indirect pathway [58]. Moreover, stimulation of B cells, in the presence of T cells, drives the naïve B cells to differentiate into memory B and plasma cells, which provides longlasting immunity against grafts [59-60].

\section{Drug targets for chronic renal transplant rejection}

Different drugs that might be helpful in reducing chronic renal transplant rejection have been summarized in Table 2. Details of these drugs are as follows. 


\section{Cureus}

\begin{tabular}{|c|c|c|c|}
\hline Drug & Category & Mechanism & Effect \\
\hline $\begin{array}{l}\text { Mycophenolate } \\
\text { mofetil }\end{array}$ & $\begin{array}{l}\text { Immunosuppressive } \\
\text { (Anti-proliferative) }\end{array}$ & $\begin{array}{l}\text { Inhibitor of inosine monophosphate } \\
\text { dehydrogenase (IMPDH) }\end{array}$ & $\begin{array}{l}\text { Decreases proliferation of } B \\
\text { and } T \text { cells. }\end{array}$ \\
\hline $\begin{array}{l}\text { Rapamycin } \\
\text { (Sirolimus) }\end{array}$ & $\begin{array}{l}\text { Immunosuppressive } \\
\text { (Anti-proliferative) }\end{array}$ & $\begin{array}{l}\text { Blocks Cells Cycle at the Junction of G1 and S } \\
\text { phase by interacting with intracellular protein, } \\
\text { FKBP12 and blocking cell specific kinase TOR } \\
\text { (Target of rapamycin) }\end{array}$ & $\begin{array}{l}\text { Decreases proliferation of B } \\
\text { cells, T cells, smooth } \\
\text { muscles and decreases } \\
\text { antibody production }\end{array}$ \\
\hline Everolımus & $\begin{array}{l}\text { Immunosuppressive } \\
\text { (Anti-proliferative) }\end{array}$ & Same as Rapamycin (Sirolimus) & $\begin{array}{l}\text { Same as Rapamycin } \\
\text { (Sirolimus) }\end{array}$ \\
\hline Leflunomide & $\begin{array}{l}\text { Immunosuppressive } \\
\text { (Anti-proliferative) }\end{array}$ & $\begin{array}{l}\text { Blocks the action of dihydroorotate } \\
\text { dehydrogenase, which is a rate-limiting enzyme } \\
\text { in the production of uridine monophosphate } \\
\text { (UMP). }\end{array}$ & $\begin{array}{l}\text { Decreases proliferation and } \\
\text { differentiation of activated } \\
\text { lymphocytes }\end{array}$ \\
\hline Azithioprine & $\begin{array}{l}\text { Immunosuppressıve } \\
\text { (Anti-proliferative) }\end{array}$ & Blocks de novo purine synthesis & Blocks $\mathrm{T}$ cell activation \\
\hline Methylprednisolone & $\begin{array}{l}\text { Immunosuppressive } \\
\text { (Anti-proliferative } \\
\text { and anti- } \\
\text { inflammatory) }\end{array}$ & $\begin{array}{l}\text { Causes redistribution of I cells and blocks } \\
\text { inflammatory pathways }\end{array}$ & $\begin{array}{l}\text { Decreases circulating I } \\
\text { cells and inflammatory } \\
\text { cytokines (for instance IL-6) }\end{array}$ \\
\hline $\begin{array}{l}\text { Tacrolimus } \\
\text { (FK506) }\end{array}$ & $\begin{array}{l}\text { Immunosuppressive } \\
\text { (Anti-proliferative } \\
\text { and antibiotic) }\end{array}$ & Causes decrease in gene expression & $\begin{array}{l}\text { Decreases both cell- } \\
\text { mediated and humoral } \\
\text { immunity }\end{array}$ \\
\hline Rituximab & $\begin{array}{l}\text { (Anti-proliferative, } \\
\text { anti-CD20 } \\
\text { monoclonal } \\
\text { antibody) }\end{array}$ & $\begin{array}{l}\text { Antibody-dependent cellular cytotoxicity, direct } \\
\text { signaling and antibody-mediated cytotoxicity }\end{array}$ & $\begin{array}{l}\text { Decreases the population } \\
\text { of CD20 B cells. }\end{array}$ \\
\hline
\end{tabular}

TABLE 2: Major drugs, their group, mechanism of actions and effects

Mycophenolate Mofetil

Mycophenolate mofetil (MMF) is a pro-drug for mycophenolic acid (MPA). It is an inhibitor of the inosine monophosphate dehydrogenase (IMPDH). It is an enzyme that controls the rate-limiting steps in the de novo production of guanosine nucleotides. $\mathrm{T}$ and $\mathrm{B}$ cells are more dependent on this pathway than any other cell [61-62]. Mycophenolate has been shown to have far more superior immunosuppressive properties as compared to azathioprine, and it can significantly reduce the chances of acute graft rejection [63]. However, its benefits in terms of long-term graft survival still need to be elucidated. Multiple studies have shown that the use of mycophenolate mofetil over an extended period can significantly reduce the chance of long-term graft rejection and can increase the mean survival of the transplant [64-65].

Rapamycin 
Rapamycin (sirolimus), which was initially discovered as an antifungal agent, has now been shown to have significant anti-cancer and immunosuppressant activities. It blocks cell cycle at the junction of G1 and S phase by interacting with intracellular protein, FKBP12, and blocking cell specific kinase TOR (target of rapamycin) [66-67]. Several studies have shown that use of rapamycin in the maintenance regime after transplants can lead to immune suppression, decrease in smooth muscle proliferation, a decrease in the chances of acute and sub-acute transplant rejection, and improve the long-term survival and function of renal allografts [68-70].

\section{Everolimus}

Everolimus is a more polar version of rapamycin (sirolimus). Its mechanism of action and effects are essentially the same as rapamycin [71-73]. Data collected from pre-clinical studies have shown that everolimus not only improves the survival in response to acute graft rejection but also helps in the long-term survival of the grafts [72-74].

\section{Leflunomide}

Leflunomide is a drug that is widely used for the treatment of auto-immune disorders, like rheumatoid arthritis (RA), due to its potent immune-suppressive effects. The metabolites from leflunomide block the action of dihydroorotate dehydrogenase, which is a rate-limiting enzyme in the production of uridine monophosphate (UMP). Activated lymphocytes need UMP for proliferation and differentiation [75-77]. Leflunomide has been shown to decrease acute graft rejection [78-80]. Moreover, its use in animal models has been shown to decrease the development and progression of CAN in the transplanted tissues [81-82]. Results of a study showed that leflunomide was superior to azathioprine or mycophenolate mofetil in improving renal functions in transplant patients with deteriorating kidney functions. Moreover, its use decreased the progression and rather initiated the reversal of CAN features [83].

\section{Azathioprine}

Azathioprine is a purine analog that functions at the level of DNA [84-85]. It is quickly metabolized into 6-mercaptopurine (6-MP), which gets incorporated into the DNA and thereby decreases the de novo purine synthesis [86]. Azathioprine blocks CD28 signaling and T cell activation [87]. Studies have shown that shifting patients from the conventional cyclosporine A therapy to azathioprine therapy can improve the survival of graft and can decrease the chances of nephrotoxicity seen with cyclosporine [88].

\section{Methylprednisolone}

Methylprednisolone decreases the chances of chronic graft rejection by suppressing several immunological and inflammatory mechanisms. The exact mechanism by which the methylprednisolone accomplishes this feat is still uncertain, but two mechanisms are worth mentioning here. First, the administration of steroids causes the redistribution of $\mathrm{T}$ cells from the circulation into other body compartments (for instance, to bone marrow), which renders these cells almost ineffective [89-90]. Second, the administration of methylprednisolone also seems to decrease the production of inflammatory cytokines [91]. There are some reports that favor short, but not long-term, use of methylprednisolone as it reduces the chances of acute graft rejection and thereby, rather indirectly, improves the long-term survival of transplant patients [92].

\section{Tacrolimus}

Tacrolimus (FK506) is a macrolide antibiotic with immunosuppressive activity as well. Although its structure is different from cyclosporine, its mechanism of action is essentially the same as that of cyclosporine. It causes impairment in the expression of targeted genes in the targeted cells. 
Tacrolimus binds to an immunophilin, FK506 binding protein (FKBP), which then inhibits the activity of calcineurin phosphatase. Inhibition of calcineurin phosphatase suppresses the activity of several genes, such as genes involved in cell degranulation, interleukin-2 transcription, and so on. These effects of tacrolimus then inhibit the proliferation of $\mathrm{T}$ cells and their related cytokines. In addition, it also decreases the proliferation of B cells and antibody formation through an indirect effect, i.e. decrease in the activity of $\mathrm{T}$ cells, and suppresses the activation of B cells as well [93-94]. Tacrolimus has shown its efficacy over different conventional immunosuppressive agents in different clinical studies. It is less nephrotoxic as compared to cyclosporine and ensures the long-term conservation of kidney structure and function [95]. Moreover, it has an enhanced efficacy when used in combination with other immunosuppressive agents, such as MMF [96].

\section{Rituximab}

Rituximab is an anti-CD20 monoclonal antibody that significantly thins down the B cell population. Antibody-dependent cellular cytotoxicity, direct signaling, and antibody-mediated cytotoxicity are all the important pieces in its mechanism of action [97-99].There is some evidence that support the use of rituximab for improving the long-term survival of the kidneys [100-101].

\section{Conclusions}

To conclude, the long-term survival of renal transplants is still poor. Different risk factors, like HLA-mismatching, acute episodes of rejection, mismatch of the donor-recipient age, the age of transplant, and race, contribute the most towards decreasing the long-term survival of kidneys. Moreover, both pillars of the immune system, i.e. cell-mediated immunity and humoral immunity, play a part in the rejection of kidneys in the long run. Therefore, improving the longterm survival of kidneys should include two important things. The first proactive step is to minimize the known risk factors before the actual renal transplantation. The second step is the usage of different anti-proliferative agents that can decrease the proliferation and action of immune cells to decrease the chances of graft rejection in the longer run. The choice of drugs for the same should be made only after vigilant consideration of multiple factors that are discussed in the review and should always be patient-specific.

\section{Additional Information}

\section{Disclosures}

Conflicts of interest: In compliance with the ICMJE uniform disclosure form, all authors declare the following: Payment/services info: All authors have declared that no financial support was received from any organization for the submitted work. Financial relationships: All authors have declared that they have no financial relationships at present or within the previous three years with any organizations that might have an interest in the submitted work. Other relationships: All authors have declared that there are no other relationships or activities that could appear to have influenced the submitted work.

\section{References}

1. Chapman JR: What are the key challenges we face in kidney transplantation today? . Transplantation Res. 2013, 2:S1.

2. Nair R, Agrawal N, Lebaeau M, Tuteja S, Chandran PK, Suneja M: Late acute kidney transplant rejection: clinicopathological correlates and response to corticosteroid therapy. Transplant Proc. 2009, 41:4150-53. 10.1016/j.transproceed.2009.09.074

3. Joosten SA, Sijpkens YW, van Kooten C, Paul LC: Chronic renal allograft rejection: pathophysiologic considerations. Kidney Int. 2005, 68:1-13. 10.1111/j.1523-1755.2005.00376.x

4. Hariharan S, Johnson CP, Bresnahan BA, Taranto SE, McIntosh MJ, Stablein D: Improved graft 
survival after renal transplantation in the United States, 1988 to 1996. N Engl J Med. 2000, 342:605-12. 10.1056/NEJM200003023420901

5. Paul LC: Chronic allograft nephropathy: An update. Kidney Int. 1999, 56:783-93. 10.1046/j.1523-1755.1999.00611.x

6. Clayton P, Campbell S, Hurst K, McDonald S, Chadban S: Transplantation. ANZDATA Registry Report 2010, Australia and New Zealand Dialysis and Transplant Registry Adelaide, South Australia. 2011, pg 8-1 - 8-31. Accessed: November 5, 2015:

http://www.anzdata.org.au/anzdata/AnzdataReport/34thReport/2011c08 transplantation_v1.7.pdf

7. Arend SM, Mallat MJ, Westendorp RJ, van der Woude FJ, van Es LA: Patient survival after renal transplantation; more than 25 years follow-up. Nephrol Dial Transplant. 1997, 12:1672-79. 10.1093/ndt/12.8.1672

8. Paul LC, Hayry P, Foegh M, Dennis MJ, Mihatsch MJ, Larsson E, Fellström B: Diagnostic criteria for chronic rejection/accelerated graft atherosclerosis in heart and kidney transplants: joint proposal from the Fourth Alexis Carrel Conference on Chronic Rejection and Accelerated Arteriosclerosis in Transplanted Organs. Transplant Proc. 1993, 25:2022-23.

9. Kasiske BL, Andany MA, Danielson B: A thirty percent chronic decline in inverse serum creatinine is an excellent predictor of late renal allograft failure. Am J Kidney Dis. 2002, 39:76268. 10.1053/ajkd.2002.31996

10. Massy ZA, Guijarro C, Wiederkehr MR, Ma JZ, Kasiske BL: Chronic renal allograft rejection: Immunologic and nonimmunologic risk factors. Kidney Int. 1996, 49:518-24. 10.1038/ki.1996.74

11. Nankivell BJ, Borrows RJ, Fung CL, O'Connell PJ, Allen RD, Chapman JR: The natural history of chronic allograft nephropathy. N Engl J Med. 2003, 349:2326-33. 10.1056/NEJMoa020009

12. Mauiyyedi S, Colvin RB: Pathology of kidney transplantation. Kidney Transplantation: Principles and Practice, 5th edition. Morris PJ, Knechtle SJ (ed): WB Saunders Company, Oxford; 2001. 343-376.

13. Freese P, Svalander CT, Mölne J, Nordén G, Nyberg G: Chronic allograft nephropathy-biopsy findings and outcome. Nephrol Dial Transplant. 2001, 16:2401-6. 10.1093/ndt/16.12.2401

14. Boersema M, Rienstra H, van den Heuvel M, van Goor H, van Luyn MJ, Navis GJ, Popa ER, Hillebrands JL: Donor and recipient contribution to transplant vasculopathy in chronic renal transplant dysfunction. Transplantation. 2009, 88:1386-92. 10.1097/TP.0b013e3181bca1e4

15. Ivanyi B: Transplant capillaropathy and transplant glomerulopathy: Ultrastructural markers of chronic renal allograft rejection. Nephrol Dial Transplant. 2003, 18:655-60. 10.1093/ndt/gfg139

16. Grimm PC, Nickerson P, Jeffery J, Savani RC, Gough J, McKenna RM, Stern E, Rush DN: Neointimal and tubulointerstitial infiltration by recipient mesenchymal cells in chronic renalallograft rejection. N Engl J Med. 2001, 345:93-97. 10.1056/NEJM200107123450203

17. Lepage S, Cailhier JF: Chronic transplant vasculopathy microenvironment present in the renal allograft reprograms macrophage phenotype. Transplant Proc. 2009 , 41:3311-13. 10.1016/j.transproceed.2009.08.035

18. Maryniak RK, First MR, Weiss MA: Transplant glomerulopathy: Evolution of morphologically distinct changes. Kidney Int. 1985, 27:799-806. 10.1038/ki.1985.83

19. Cosio FG, Frankel WL, Pelletier RP, Pesavento TE, Henry ML, Ferguson RM: Focal segmental glomerulosclerosis in renal allografts with chronic nephropathy: implications for graft survival. Am J Kidney Dis. 1999, 34:731-38. 10.1016/S0272-6386(99)70400-2

20. Joosten SA, van Kooten C, Sijpkens YW, de Fijter JW, Paul LC: The pathobiology of chronic allograft nephropathy: immune-mediated damage and accelerated aging. Kidney Int. 2004, 65:1556-59. 10.1111/j.1523-1755.2004.05410.x

21. Andresdottir MB, Assmann KJ, Koene RA, Wetzels JF: Immunohistological and ultrastructural differences between recurrent type I membranoproliferative glomerulonephritis and chronic transplant glomerulopathy. Am J Kidney Dis. 1998, 32:582-88. 10.1016/S0272-6386(98)70020-4

22. Lindholm A, Ohlman S, Albrechtsen D, Tufveson G, Persson H, Persson NH: The impact of acute rejection episodes on long-term graft function and outcome in 1347 primary renal transplants treated by 3 cyclosporine regimens. Transplantation. 1993, 56:307-315. 10.1097/00007890199308000-00010

23. Opelz G: New immunosuppressants and HLA matching. Transplant Proc. 2001, 33:467-68. 10.1016/S0041-1345(00)02095-9

24. McKenna RM, Takemoto SK,Terasaki PI: Anti-HLA antibodies after solid organ transplantation . Transplantation. 2000, 69:319-26. 10.1097/00007890-200002150-00001

25. Lee PC, Terasaki PI, Takemoto SK, Lee PH, Hung CJ, Chen YL, Tsai A, Lei HY: All chronic rejection failures of kidney transplants were preceded by the development of HLA antibodies. 
Transplantation. 2002, 74:1192-94. 10.1097/00007890-200210270-00025

26. Piazza A, Poggi E, Borrelli L, Servetti S, Monaco PI, Buonomo O, Valeri M, Torlone N, Adorno D, Casciani CU: Impact of donor-specific antibodies on chronic rejection occurrence and graft loss in renal transplantation: posttransplant analysis using flow cytometric techniques.

Transplantation. 2001, 71:1106-12. 10.1097/00007890-200104270-00017

27. Süsal C, Opelz G: Kidney graft failure and presensitization against HLA class I and class II antigens. Transplantation. 2002, 73:1269-73. 10.1097/00007890-200204270-00014

28. Bradley BA: Rejection and recipient age. Transpl Immunol. 2002, 10:125-32. 10.1016/S09663274(02)00058-8

29. Raiz LR, Kilty KM, Henry ML, Ferguson RM: Medication compliance following renal transplantation. Transplantation. 1999, 68:51-55. 10.1097/00007890-199907150-00010

30. Levine MH, Reese PP, Wood A, Baluarte JH, Huverserian A, Naji A, Abt PL: Inferior allograft outcomes in adolescent recipients of renal transplants from ideal deceased donors. Ann Surg. 2012, 255:556-64. 10.1097/SLA.0b013e3182471665

31. Lim WH, Chang S, Chadban S, Campbell S, Dent H, Russ GR, McDonald SP: Donor-recipient age matching improves years of graft function in deceased-donor kidney transplantation. Nephrol Dial Transplant. 2010 , 25:3082-89. 10.1093/ndt/gfq127

32. Feldman HI, Gayner R, Berlin JA, Roth DA, Silibovsky R, Kushner S, Brayman KL, Burns JE, Kobrin SM, Friedman AL, Grossman RA: Delayed function reduces renal allograft survival independent of acute rejection. Nephrol Dial Transplant. 1996, 11:1306-13. 10.1093/ndt/11.7.1306

33. Flechner SM, Modlin CS, Serrano DP, Goldfarb DA, Papajcik D, Mastroianni B, Goormastic M, Novick AC: Determinants of chronic renal allograft rejection in cyclosporine-treated recipients. Transplantation. 1996, 62:1235-41. 10.1097/00007890-199611150-00009

34. Young CJ, Gaston RS: Renal transplantation in black Americans. N Engl J Med. 2000, 343:154552. 10.1056/NEJM200011233432107

35. Paul LC: Glomerular hypertension-An under-appreciated aspect of chronic rejection . Nephrol Dial Transplant. 2001, 16:213-15. 10.1093/ndt/16.2.213

36. Mange KC, Cizman B, Joffe M, Feldman HI: Arterial hypertension and renal allograft survival . JAMA. 2000, 283:633-38. 10.1001/jama.283.5.633

37. van Es LA, Sijpkens YW, Paul LC: Surrogate markers of chronic allograft nephropathy . Ann Transplant. 2000, 5:7-11.

38. Guijarro C, Massy ZA, Kasiske BL: Clinical correlation between renal allograft failure and hyperlipidemia. Kidney Int Suppl. 1995, 52:S56-59.

39. Sung RS, Althoen M, Howell TA, Ojo AO, Merion RM: Excess risk of renal allograft loss associated with cigarette smoking. Transplantation. 2001, 71:1752-57. 10.1097/00007890200106270-00009

40. Smits JM, van Houwelingen HC, De Meester J, le Cessie S, Persijn GG, Claas FH, Frei U: Permanent detrimental effect of nonimmunological factors on long-term renal graft survival: a parsimonious model of time-dependency. Transplantation. 2000, 70:317-23.

10.1097/00007890-200007270-00015

41. Takemoto SK, Terasaki PI, Gjertson DW, Cecka JM: Twelve years' experience with national sharing of HLA-matched cadaveric kidneys for transplantation. N Engl J Med. 2000, 343:107884. 10.1056/NEJM200010123431504

42. Ingulli E: Mechanism of cellular rejection in transplantation. Pediatr Nephrol. 2010, 25:61-74. 10.1007/s00467-008-1020-x

43. Sayegh MH: Why do we reject a graft? Role of indirect allorecognition in graft rejection . Kidney Int. 1999, 56:1967-79. 10.1046/j.1523-1755.1999.00751.x

44. Womer KL, Stone JR, Murphy B, Chandraker A, Sayegh MH: Indirect allorecognition of donor class I and II major histocompatibility complex peptides promotes the development of transplant vasculopathy. J Am Soc Nephrol. 2001, 12:2500-6.

45. Ciubotariu R, Liu Z, Colovai AI, Ho E, Itescu S, Ravalli S, Hardy MA, Cortesini R, Rose EA, SuciuFoca N: Persistent allopeptide reactivity and epitope spreading in chronic rejection of organ allografts. J Clin Invest. 1998, 101:398-405. 10.1172/JCI1117

46. Vella JP, Spadafora-Ferreira M, Murphy B, Alexander SI, Harmon W, Carpenter CB, Sayegh MH: Indirect allorecognition of major histocompatibility complex allopeptides in human renal transplant recipients with chronic graft dysfunction. Transplantation. 1997, 64:795-800. 10.1097/00007890-199709270-00001

47. Chan SY, DeBruyne LA, Goodman RE, Eichwald EJ, Bishop DK: In vivo depletion of CD8+ T cells 
results in Th2 cytokine production and alternate mechanisms of allograft rejection.

Transplantation. 1995, 59:1155-61.

48. Shirwan H, Barwari L, Khan NS: Predominant expression of T helper 2 cytokines and altered expression of $\mathrm{T}$ helper 1 cytokines in long-term allograft survival induced by intrathymic immune modulation with donor class I major histocompatibility complex peptides.

Transplantation. 1998, 66:1802-9. 10.1097/00007890-199812270-00039

49. VanBuskirk AM, Wakely ME, Orosz CG: Transfusion of polarized TH2-like cell populations into SCID mouse cardiac allograft recipients results in acute allograft rejection. Transplantation. 1996, 62:229-38. 10.1097/00007890-199607270-00014

50. Le Moine A, Flamand V, Demoor FX, Noël JC, Surquin M, Kiss R, Nahori MA, Pretolani M, Goldman M, Abramowicz D: Critical roles for IL-4, IL-5, and eosinophils in chronic skin allograft rejection. J Clin Invest. 1999, 103:1659-67. 10.1172/JCI5504

51. Postlethwaite AE, Holness MA, Katai H, Raghow R: Human fibroblasts synthesize elevated levels of extracellular matrix proteins in response to interleukin 4. J Clin Invest. 1992, 90:14791485. 10.1172/JCI116015

52. Lacraz S, Nicod LP, Chicheportiche R, Welgus HG, Dayer JM: IL-10 inhibits metalloproteinase and stimulates TIMP-1 production in human mononuclear phagocytes. J Clin Invest. 1995, 96:2304-10. 10.1172/JCI118286

53. Mosmann TR, Cherwinski H, Bond MW, Giedlin MA, Coffman RL: Two types of murine helper T cell clone. I. Definition according to profiles of lymphokine activities and secreted proteins. J Immunol. 1986, 136:2348-57.

54. Hippen BE, DeMattos A, Cook WJ, Kew CE 2nd, Gaston RS: Association of CD20+ infiltrates with poorer clinical outcomes in acute cellular rejection of renal allografts. Am J Transplant. 2005, 5:2248-52. 10.1111/j.1600-6143.2005.01009.x

55. Lehnhardt A, Mengel M, Pape L, Ehrich JH, Offner G, Strehlau J: Nodular B-cell aggregates associated with treatment refractory renal transplant rejection resolved by rituximab. Am J Transplant. 2006, 6:847-51. 10.1111/j.1600-6143.2006.01246.x

56. Racusen LC, Colvin RB, Solez K, Mihatsch MJ, Halloran PF, Campbell PM, Cecka MJ, Cosyns JP, Demetris AJ, Fishbein MC, Fogo A, Furness P, Gibson IW, Glotz D, Hayry P, Hunsickern L, Kashgarian M, Kerman R, Magil AJ, Montgomery R, Morozumi K, Nickeleit V, Randhawa P, Regele H, Seron D, Seshan S, Sund S, Trpkov K: Antibody-mediated rejection criteria - an addition to the Banff 97 classification of renal allograft rejection. Am J Transplant. 2003, 3:70814. 10.1034/j.1600-6143.2003.00072.x

57. Solez K, Colvin RB, Racusen LC, Haas M, Sis B, Mengel M, Halloran PF, Baldwin W, Banfi G, Collins AB, Cosio F, David DS, Drachenberg C, Einecke G, Fogo AB, Gibson IW, Glotz D, Iskandar SS, Kraus E, Lerut E, Mannon RB, Mihatsch M, Nankivell BJ, Nickeleit V, Papadimitriou JC, Randhawa P, Regele H, Renaudin K, Roberts I, Seron D, Smith RN, Valente M: Banff 07 classification of renal allograft pathology: updates and future directions. Am J Transplant. 2008, 8:753-60. 10.1111/j.1600-6143.2008.02159.x

58. Alegre ML, Florquin S, Goldman M: Cellular mechanisms underlying acute graft rejection: time for reassessment. Curr Opin Immunol. 2007, 19:563-68. 10.1016/j.coi.2007.07.019

59. Lanzavecchia A, Bernasconi N, Traggiai E, Ruprecht CR, Corti D, Sallusto F: Understanding and making use of human memory B cells. Immunol Rev. 2006, 211:303-9. 10.1111/j.01052896.2006.00403.X

60. Bernasconi NL, Traggiai E, Lanzavecchia A: Maintenance of serological memory by polyclonal activation of human memory B cells. Science. 2002, 298:2199-202. 10.1126/science.1076071

61. Allison AC, Eugui EM: Mycophenolate mofetil and its mechanisms of action . Immunopharmacology. 2000, 47:85-118. 10.1016/S0162-3109(00)00188-0

62. Villarroel MC, Hidalgo M, Jimeno A: Mycophenolate mofetil: An update. Drugs Today. 2009, 45:521-32. 10.1358/dot.2009.45.7.1384878

63. Wüthrich RP1, Weinreich T, Ambühl PM, Schwarzkopf AK, Candinas D, Binswanger U: Reduced kidney transplant rejection rate and pharmacoeconomic advantage of mycophenolate mofetil.

Nephrol Dial Transplant. 1999, 14:394-99. 10.1093/ndt/14.2.394

64. Meier-Kriesche HU, Steffen BJ, Hochberg AM, Gordon RD, Liebman MN, Morris JA, Kaplan B: Mycophenolate mofetil versus azathioprine therapy is associated with a significant protection against long-term renal allograft function deterioration. Transplantation. 2003, 75:1341-46. 10.1097/01.TP.0000062833.14843.4B

65. Meier-Kriesche HU, Steffen BJ, Hochberg AM, Gordon RD, Liebman MN, Morris JA, Kaplan B: Long-term use of mycophenolate mofetil is associated with a reduction in the incidence and risk 
of late rejection. Am J Transplant. 2003, 3:68-73. 10.1034/j.1600-6143.2003.30112.x

66. Crespo JL, Hall MN: Elucidating TOR signaling and rapamycin action: lessons from Saccharomyces cerevisiae. Microbiol Mol Biol Rev. 2002, 66:579-91. 10.1128/MMBR.66.4.579591.2002

67. Sehgal SN: Sirolimus its discovery, biological properties, and mechanism of action . Transplant Proc. 2003, 35:7S-14S. 10.1016/S0041-1345(03)00211-2

68. Kahan BD, Julian BA, Pescovitz MD, Vanrenterghem Y, Neylan J: Sirolimus reduces the incidence of acute rejection episodes despite lower cyclosporine doses in caucasian recipients of mismatched primary renal allografts: a phase II trial. Rapamune Study Group. Transplantation. 1999, 68:1526-32. 10.1097/00007890-199911270-00016

69. Gallon L, Perico N, Dimitrov BD, Winoto J, Remuzzi G, Leventhal J, Gaspari F, Kaufman D: Longterm renal allograft function on a tacrolimus-based, pred-free maintenance immunosuppression comparing sirolimus vs. MMF. Am J Transplant. 2006, 6:1617-23. 10.1111/j.16006143.2006.01340.x

70. Oberbauer R, Kreis H, Johnson RW, Mota A, Claesson K, Ruiz JC, Wilczek H, Jamieson N, Henriques AC, Paczek L, Chapman J, Burke JT, Rapamune Maintenance Regimen Study Group: Long-term improvement in renal function with sirolimus after early cyclosporine withdrawal in renal transplant recipients: 2-year results of the Rapamune Maintenance Regimen Study. Transplantation. 2003, 76:364-70. 10.1097/01.TP.0000074360.62032.39

71. Kirchner GI, Meier-Wiedenbach I, Manns MP: Clinical pharmacokinetics of everolimus. Clin Pharmacokinet. 2004, 43:83-95. 10.2165/00003088-200443020-00002

72. Sánchez-Fructuoso AI: Everolimus: an update on the mechanism of action, pharmacokinetics and recent clinical trials. Expert Opin Drug Metab Toxicol. 2008, 4:807-19. 10.1517/17425255.4.6.807

73. Lavigne MC, Grimsby JL, Eppihimer MJ: Antirestenotic mechanisms of everolimus on human coronary artery smooth muscle cells: inhibition of human coronary artery smooth muscle cell proliferation, but not migration. J Cardiovasc Pharmacol. 2012, 59:165-74.

10.1097/FJC.0b013e31823a39c7

74. Nashan B: Review of the proliferation inhibitor everolimus. Expert Opin Investig Drugs. 2002, 11:1845-57. 10.1517/13543784.11.12.1845

75. Herrmann ML, Schleyerbach R, Kirschbaum BJ: Leflunomide: an immunomodulatory drug for the treatment of rheumatoid arthritis and other autoimmune diseases. Immunopharmacology. 2000, 47:273-89. 10.1016/S0162-3109(00)00191-0

76. Fox RI, Herrmann ML, Frangou CG, Wahl GM, Morris RE, Strand V, Kirschbaum BJ: Mechanism of action for leflunomide in rheumatoid arthritis. Clin Immunol. 1999, 93:198-208. 10.1006/clim.1999.4777

77. Breedveld F, Dayer J: Leflunomide mode of action in the treatment of rheumatoid arthritis . Ann Rheum Dis. 2000, 59:841-49. 10.1136/ard.59.11.841

78. Williams JW, Xiao F, Foster P, Clardy C, McChesney L, Sankary H, Chong AS: Leflunomide in experimental transplantation. Control of rejection and alloantibody production, reversal of acute rejection, and interaction with cyclosporine. Transplantation. 1994, 57:1223-1231.

79. Xiao F, Chong A, Foster P, Sankary H, McChesney L, Williams JM, Frieders D, Williams JW: Effect of leflunomide in control of acute rejection in hamster-to-rat cardiac xenografts . Transplant Proc. 1994, 26:1263-65.

80. Foster PF, Xiao F, Kociss K, Chong AS, Sankary HN, McChesney L, Cohn S, Williams JW: Leflunomide immunosuppression in rat small intestinal transplantation. Transplant Proc. 1994, 26:1599-600.

81. Xiao F, Chong A, Shen J, Yang J, Short J, Foster P, Sankary H, Jensik S, Mital D, McChesney L: Pharmacologically induced regression of chronic transplant rejection . Transplantation. 1995, 60:1065-72.

82. Morris RE, Huang X, Gregory CR, Billingham ME, Rowan R, Shorthouse R, Berry GJ: Studies in experimental models of chronic rejection: use of rapamycin (sirolimus) and isoxazole derivatives (leflunomide and its analogue) for the suppression of graft vascular disease and obliterative bronchiolitis. Transplant Proc. 1995, 27:2068-69.

83. Hardinger KL, Wang CD, Schnitzler MA, Miller BW, Jendrisak MD, Shenoy S, Lowell JA, Brennan DC: Prospective, pilot, open-label, short-term study of conversion to leflunomide reverses chronic renal allograft dysfunction. Am J Transplantation. 2002, 2:867-71. 10.1034/j.16006143.2002.20909.x

84. Elion GB: The George Hitchings and Gertrude Elion Lecture. The pharmacology of azathioprine . 
Ann N Y Acad Sci. 1993, 685:400-7. 10.1111/j.1749-6632.1993.tb35896.x

85. Aarbakke J, Janka-Schaub G, Elion GB: Thiopurine biology and pharmacology. Trends Pharmacol Sci. 1997, 18:3-7. 10.1016/S0165-6147(96)01007-3

86. Jonathan MS, Koretzky GA: Azathioprine: old drug, new actions. J Clin Invest. 2003, 111:112224. 10.1172/JCI200318384

87. Tiede I, Fritz G, Strand S, Poppe D, Dvorsky R, Strand D, Lehr HA, Wirtz S, Becker C, Atreya R, Mudter J, Hildner K, Bartsch B, Holtmann M, Blumberg R, Walczak H, Iven H, Galle PR, Ahmadian MR, Neurath MF: CD28-dependent Rac1 activation is the molecular target of azathioprine in primary human CD4+ T lymphocytes. J Clin Invest. 2003, 111:1133-45. 10.1172/JCI200316432

88. Pedersen EB, Hansen HE, Kornerup HJ, Madsen S, Sørensen AW: Long-term graft survival after conversion from cyclosporin to azathioprine 1 year after renal transplantation. A prospective, randomized study from 1 to 6 years after transplantation. Nephrol Dial Transplant. 1993, 8:25054.

89. Fauci AS, Dale DC: Alternate-day prednisone therapy and human lymphocyte subpopulations. J Clin Invest. 1975, 55:22-32. 10.1172/JCI107914

90. Rota S, Rambaldi A, Gaspari F, Noris M, Daina E, Benigni A, Perna A, Donadelli R, Remuzzi G, Garattini S: Methylprednisolone dosage effects on peripheral lymphocyte subpopulations and eicosanoid synthesis. Kidney Int. 1992, 42:981-90. 10.1038/ki.1992.377

91. Pulitanò C, Aldrighetti L, Arru M, Finazzi R, Catena M, Guzzetti E, Soldini L, Comotti L, Ferla G: Preoperative methylprednisolone administration maintains coagulation homeostasis in patients undergoing liver resection: importance of inflammatory cytokine modulation. Shock. 2007, 28:401-5. 10.1097/shk.0b013e318063ed11

92. Qvist E, Their M, Krogerus L, Holmberg C, Jalanko H: Early treatment of acute rejections gives favorable long-term function after renal transplantation in small children. Pediatr Transplant. 2007, 11:895-900. 10.1111/j.1399-3046.2007.00761.x

93. Thomson AW, Bonham CA, Zeevi A: Mode of action of tacrolimus (FK506): molecular and cellular mechanisms. Ther Drug Monit. 1995, 17:584-91.

94. Brazelton TR, Morris RE: Molecular mechanisms of action of new xenobiotic immunosuppressive drugs: tacrolimus (FK506), sirolimus (rapamycin), mycophenolate mofetil and leflunomide. Curr Opin Immunol. 1996, 8:710-20. 10.1016/S0952-7915(96)80090-2

95. Jurewicz WA: Tacrolimus versus ciclosporin immunosuppression: long-term outcome in renal transplantation. Nephrol Dial Transplant. 2003, 18: i7-i11. 10.1093/ndt/gfg1028

96. Gallon L, Perico N, Dimitrov BD, Winoto J, Remuzzi G, Leventhal J, Gaspari F, Kaufman D: Longterm renal allograft function on a tacrolimus-based, pred-free maintenance immunosuppression comparing sirolimus vs MMF. Am J Transplant. 2006, 6:1617-23. 10.1111/j.16006143.2006.01340.x

97. Weiner GJ: Rituximab: mechanism of action. Semin Hematol. 2010, 47:115-23. 10.1053/j.seminhematol.2010.01.011

98. Maloney DG, Smith B, Rose A: Rituximab mechanism of action and resistance. Semin Oncol. 2002, 29:2-9. 10.1053/sonc.2002.30156

99. Cerny T, Borisch B, Introna M, Johnson P, Rose AL: Mechanism of action of rituximab. Anticancer Drugs. 2002, 13:S3-10.

100. Salama AD, Pusey CD: Drug Insight: rituximab in renal disease and transplantation. Nat Clin Pract Nephrol. 2006, 2:221-30. 10.1038/ncpneph0133

101. Genberg H, Kumlien G, Wennberg L, Tydén G: Long-term results of ABO-incompatible kidney transplantation with antigen-specific immunoadsorption and rituximab. Transplantation. 2007, 84:S44-S47. 10.1097/01.tp.0000296031.41424.f8 